Przegląd Badań Edukacyjnych Educational Studies Review

ISSN 1895-4308

nr 25 (2/2017), s. 39-58

METAANALIZY

BADAŃ

Bogusław Śliwerski

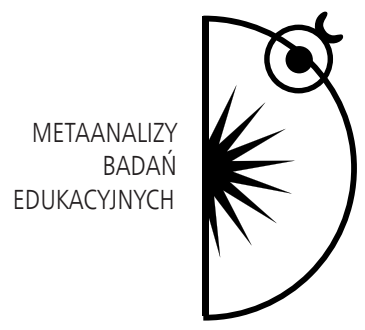

Uniwersytet Łódzki, e-mail: boguslawsliwerski@gmail.com

\title{
Paradygmaty współczesnej pedagogiki jedności w Polsce
}

http://dx.doi.org/10.12775/PBE.2017.018

\section{Paradigms of Contemporary Pedagogics of Unity in Poland}

\section{Abstract:}

The subject of the analysis is three approaches to education in contemporary Christian pedagogics in Poland with the corresponding ideas (as central categories): 1) the idea of universalism; 2) the idea of holism and 3) the idea of post- and interdisciplinary pedagogics. The author characterizes the contribution of Polish pedagogical thought and selected achievements of scholars in building the pedagogics of unity in the world.

Keywords: pedagogics, universalism, holism, ecumenism, theology of process, post-disciplinarity, interdisciplinarity, contemporary pedagogical thought

Wiedza o wychowaniu i kształceniu jako całość historycznie, społecznie i politycznie zmiennych podejść badawczych powstaje oraz rozwija się po części w sposób kumulatywny, dialogowy, ewolucyjny, jak i rewolucyjny. Uczeni rekonstruując określone podejście czy nurt pedagogiczny tworzą w epoce własnego życia i aktywności twórczej w pewnym sensie nowe paradygmaty, bowiem wpisują w nie współczesny punkt widzenia. Niektórzy uwzględniają część z minionej perspektywy poznawczej, ale zarazem nadają jej nową interpretację. W obliczu różnych metod badań, komplementarnych, sprzecznych czy dialogu- 
jących ze sobą, historyczna ciągłość poznania wiąże się zarazem z historyczną nieciągłością.

Do przełomu w danej nauce dochodzi wówczas, gdy paradygmat aktualnie znajdujący się w centrum, ustępuje innemu, dotąd funkcjonującemu na uboczu, a będącemu w mniej lub bardziej jawnej opozycji czy na peryferiach wiedzy. To za pomocą jednego z wielu różnych założeń, czyli wzorców racjonalności pedagogicznej, może być opisywana, wyjaśniana, interpretowana, rozumiana i projektowana rzeczywistość pedagogiczna i konstruowana teoria pedagogiczna. Nawiązując do Thomasa Kuhna należy odnotować, że termin paradygmat należy w pedagogice rozumieć bardzo szeroko - „(...) jako podzielane przez jakąś wspólnotę naukową przekonania filozoficzne i metodologiczne co do sposobu widzenia problemów badawczych, co do rodzaju podejścia do badanych zjawisk, co do dopuszczalnych metod badawczych, co do oczekiwanych wyników pracy badawczej" (Szymański, 1997, s. 256).

W świetle tego spojrzenia na naukę różne paradygmaty - jako odrębne sposoby postrzegania świata - są wzajemnie niewspółmierne a komunikacja między nimi jest niemożliwa. Nauki humanistyczne i społeczne nie rozwijają się jedynie kumulacyjnie, progresywnie, tocząc ze sobą spór o swoje miejsce $\mathrm{w}$ centrum, o uprzywilejowaną epistemologicznie pozycję. Z jednej strony paradygmat uniemożliwia uczonemu ,obiektywne” postrzeganie takiej rzeczywistości, ,jaka ona naprawdę jest”, ponieważ Kuhn twierdzi, że taki obiektywny, bezstronny ogląd rzeczywistości samej jest filozoficznym mitem. Z drugiej zaś strony Kuhn głosi, że paradygmat, który w oczach antyrelatywistycznego obiektywisty zniekształca oglad rzeczywistości, umożliwia jednocześnie jej postrzeganie (Machnikowski, 2002, s. 12). Wielość paradygmatów nie musi wcale oznaczać ich równoprawności, ani też nie musi oznaczać, że nie ma możliwości znalezienia w każdym z nich jakiegoś elementu wspólnego, który pozwoliłby im spotkać się w mianowniku kształtowania ludzkości. To, że każdy z nich wymaga różnych wyjaśnień, sięgnięcia często do odmiennych źródeł, nie wyklucza ich możliwej jedności w wyniku zagrożeń globalnych (militarnych, klimatycznych, ekologicznych, ekonomicznych itp.) dla każdego z nich.

Nie powiodły się zapoczątkowane w XIX w. próby unifikacji nauk o wychowaniu, jak i zniszczenia ich ekumenicznej, a pluralistycznej zarazem wartości w wyniku dominujących w XX w. - szczególnie w krajach podporządkowanych ideologii totalitarnej - podejść ideologicznie wykluczających różnice. Wyrosła z filozofii polska pedagogika, wraz z dziejami jej rozpadu i atomizacji, stała się nie tylko „dzieckiem” niewdzięcznym i zaborczym owego corpus philosophicum, ale i jałowym, miałkim wytworem cywilizacji techniczo- 
-naukowej, poddając się bez reszty polityce monopartyjnej władzy. Dlatego polska pedagogika wciąż nadrabia zaległości z czasów PRL, okresu cenzury wewnątrzpaństwowej i żelaznej kurtyny w relacjach ze światem nauk państw kapitalistycznych. Nic dziwnego, że wielu z nas, zafascynowanych rozpoznaniem nieznanych dotychczas nurtów i teorii, uczestniczy w sposób mimetyczny w ich aplikowaniu do polskiej pedagogiki i praktyki wychowawczej czy dydaktycznej.

Powstały w 1989 r. stan radykalnego odcięcia się polskiej humanistyki od monistycznej, zdegenerowanej ideologicznie pedagogiki socjalistycznej jest już trwałym osiągnięciem czasów transformacji społeczno-politycznej, kulturowej i naukowej. Polska pedagogika stała się nauką zorientowaną na wartości pluralizmu i demokracji, pedagogiką otwartą na społeczeństwo obywatelskie, na różnice, wielość i obcość, na poszanowanie indywidualnej wolności. Jak pisał na początku transformacji Zbigniew Kwieciński (Kwieciński, Witkowski (red.), 1990, s. 9):

„Wielki trud czeka pedagogikę wobec wyzwań transformacji społecznej i kulturowej. Musimy zacząć wiele ścieżek od początku. Zamknąć za sobą drzwi i rozpocząć pracę od początku. Wznowić przerwane i zapomniane dyskursy, odrabiać zaległości, tłumaczyć, przypomnieć nasze zepchnięcie na margines osiągnięcia, tworzyć preferencje dla pedagogiki ogólnej, dla filozofii wychowania, otworzyć się na podstawowe teorie człowieka, społeczeństwa i kultury, na problemy globalne, otworzyć drogę i świat dla młodzieży naukowej i drogę ku nam dla tekstów i wiedzy ze świata, być bliżej nowej praktyki, odważnych innowatorów i twórców dobrej praktyki edukacyjnej. Trzeba pomóc zamilknąć pedagogice uprzednio instrumentalnie zaadoptowanej do - złej pamięci - uprzedniego systemu".

Dzisiaj, pluralizm nauk humanistycznych i społecznych jest dla pokolenia młodych pedagogów (przełomu XX i XXI w.) czymś oczywistym, naturalnym, choć zarazem wcale niełatwym w recepcji. Globalizacja w sferze nauki destabilizuje narodowe osiągnięcia poszczególnych państw i środowisk naukowych, które były przyzwyczajane do reprodukowania i kontynuowania własnych szkół badawczych. Wymusza zatem na badaczach wychodzenie poza obszar wiedzy przykrawanej do interesów własnego kraju, by korzystać $\mathrm{z}$ dokonań naukowców innych państw oraz upowszechniać w świecie wyniki własnych badań. Nie zapomniano w Polsce o dorobku minionych pokoleń, o wkładzie w rozwój nauki tych, których dzisiaj określamy mianem jej klasyków. 
Swoistego rodzaju „epidemia” czy inflacja pedagogicznych teorii, ich rozdrobnienie sprawiają, że niektórzy tracą zdolność czynienia rozróżnień między nimi i budowania kluczowych dla dualistycznie postrzeganego świata opozycji,

(...) które zawsze, z jednej strony, wskazują na wartość prawdziwą, a z drugiej, poprzez konfrontację, ustalają zestaw nie-wartości, albo wartości opozycyjnych. Jak w sytuacji takiej nadmiarowości rozproszonych wartości szacować, co jest pięknem, a co brzydotą, co prawdą, a co fałszem, co dobrem, a co złem? Gdy zbyt wiele wartości atakuje nas jednocześnie i nie mają one odniesienia w rzeczywistości, gdyż tylko przypominają one niegdysiejsze prawdziwe dylematy, cały ich system po prostu znika, nie da się ustalić (Burszta, Kuligowski, 1999, s. 97).

W moim przekonaniu należy dostrzec brak, niedostrzeganie czy wprost marginalizowanie $\mathrm{w}$ europejskiej myśli pedagogicznej niezwykle znaczącego nurtu pedagogiki chrześcijańskiej, w tym ekumenicznej. W czasach gdy młodzież kwestionuje wartości i autorytety, gubiąc się w gąszczu problemów współczesnego świata i cywilizacji, warto zastanowić się nad powrotem do wychowania w duchu wartości takich jak miłość, prawda, solidarność społeczna, wolność oraz prawa człowieka (Kunowski, 2000, s. 9). Wyjście z kryzysu ludzkiej moralności, sztuki i religii można dostrzec w powrocie do chrześcijańskich norm i wartości, na których wyrosła kultura europejska. W środowiskach pedagogicznych na ogół nie przesadnie eksponuje się jako głębokie różnice te, które rzekomo wykluczają możliwość kompromisu między liberalnym a chrześcijańskim modelem wychowania. Tymczasem wystarczy sięgnąć do „Etyki Solidarności” ks. Józefa Tischnera, by przekonać się, że jest to teza sprzeczna ze społeczną nauką Kościoła katolickiego w Polsce. Potrzebna jest zatem głęboka przemiana w kierunku nadającej sens ludzkiej egzystencji oraz będącej spoiwem integrującym Europę i Polskę jakim jest trwające przez wieki chrześcijaństwo (Jaworski, 2000, s. 2).

Ulrich Hermann (1996, s. 186) dokonując bilansu argumentacji na temat paradygmatyczności pedagogiki, która ewoluuje w kierunku niezwykle szeroko pojmowanych nauk o wychowaniu stwierdził, że dające się wyróżnić „(...) paradygmaty same przemieszczają się od okresu europejskiego Oświecenia w jakiś jeden paradygmat, a przez to następuje proces sekularyzacji człowieka wobec transcendencji, zinstrumentalizowanie jego relacji z naturą i upodmiotowienie jego postaw wobec samego siebie. Człowiek traktuje siebie jak twórcę, a zarazem stworzonego przez siebie oraz przez świat swojego codziennego życia. To rodzi ambiwalencje, paradoksy i dylematy współczesnej pedagogiki: dialektyka racjo- 
nalności i mitu, kształcenie i wyobcowanie, inteligencja instrumentalno-techniczna i racjonalność krytyczna sądzenia. A przede wszystkim: pedagogika nie może zagwarantować własnego sensu i swojej skuteczności. Ona oscyluje pomiędzy bezradnością i wszechwładnością, roszczeniem i zwątpieniem, zaś swoich zadań nie może delegować na nikogo innego". Wartości nauki nie są niezmienne, ale wartości chrześcijańskie są, toteż musimy umieć znaleźć przejście „,...) w gąszczu dyskursów z zachowaniem ich heterogeniczności" (Marzec, 2002, s. 20).

Spójrzmy na pedagogikę z co najmniej trzech perspektyw: 1) idei uniwersalizmu; 2) idei holizmu i 3) idei post- i interdyscyplinarności nauk o kształceniu i wychowaniu. Już Jan Amos Komeński wyjaśniał znaczenie pojęcia: „uniwersum=in uno versum, które oznacza jedność tego, co jest właściwe. Uniwersalność nie jest zatem połączeniem wszystkiego, co możliwe, ale odnajdywaniem tego, co jest istotne, fundamentalne, co jednoczy nas w duchu prawdy, odrzucając zarazem sądy fałszywe" (Palouš, Svobodová, 2011, s. 153). W Polsce rozwijał się świecki nurt filozofii uniwersalistycznej, ale nie stał się on bazą dla ekumenicznego łączenia różnych paradygmatów wiedzy pedagogicznej. Z kolei wyłaniająca się w ostatniej dekadzie narracja o postdyscyplinarności nauk uświadamia nam, że w wyniku globalizacji i postindustrializacji komunikacyjnej oraz rozwoju nauk kompleksowych, systematycznych w ramach poszczególnych dyscyplin wiedzy naukowej, w których prowadzi się badania systemowe, następuje gotowość do uchwycenia zróżnicowania i fragmentaryzacji myśli na rzecz dialogowego zwrotu. Nauka dąży do takiego „,...) podejścia, które wielość orientacji i perspektyw uczyni zasadniczą podstawą twórczego, owocnego dialogu" (Kojder, 2016, s. 128).

Rewolucja postindustrialna stawia pedagogikę przed szczególnym wyzwaniem budowania cywilizacji humanum, w której pomożemy dzieciom i młodzieży, ale i światu dorosłych oraz osób starszych, rozwiązywać ich codzienne problemy w realu $\mathrm{z}$ jednoczesnym zrozumieniem sensów zachodzących w wirtualnym świecie. Po raz pierwszy pedagogika musi stać się nie tyle forpocztą przemian społecznych i budowania czy współkreowania przyszłości, ale obrony człowieczeństwa w warunkach coraz bardziej dehumanizującego się świata. Nie możemy stać biernie po stronie manipulatorów, przyglądać się toksycznym zmianom i nawet krytycznie je opisywać oraz interpretować, lecz musimy zacząc interweniować, przeciwstawiać się temu, co jest patologiczne, destrukcyjne, by wzmacniać potencjał samoobronny kolejnych pokoleń wobec pazerności świata skrywającego zło.

Do pedagogiki jedności dochodzi się w wyniku badań synchronicznych, tzn. przez twórczy dialog z dyskursami sobie współczesnymi i badań dia- 
chronicznych, a więc $\mathrm{w}$ ramach dyskusji z dyskursami funkcjonującymi bądź w przeszłości, bądź z potencjalnymi zwolennikami danego nurtu w przyszłości. Rekonstrukcja kontekstu diachronicznego i synchronicznego może być budowaniem „pozytywnej” historii określonej teorii, zmierzając do pozytywnego usytuowania w synchronicznym paradygmacie danej dyscypliny wiedzy, ale również rekonstrukcją „negatywnej” historii i „negatywnego” odniesienia do paradygmatu wiedzy, kiedy to powstaje relacja „tekst-anty-tekst”, bazująca na zasadzie wzajemnego wykluczania (Panas 1991). Świat nauk pedagogicznych jest światem polinarracyjnym czy wielodyskursywnym, w którym każdy ma prawo do tworzenia swoich własnych podejść, orientacji czy nurtów z całą zarazem otwartością na to, co jest w tym świecie od nich inne.

O istocie paradygmatu jedności stanowić będzie zatem atrakcyjna siła ideału pedagogicznego ekumenizmu oraz ludzie, dla których stał się on naczelną wartością. To zgromadzeni na Kongresie Focolare uczestnicy tego wyjątkowego ruchu są nośnikami tkwiącego w nim przesłania, nasycając nim całe życie współczesne, podejście do wychowania i kształcenia oraz oświetlając jego sens. Paradygmat jedności - podobnie jak te dualistyczne czy monistyczne - powstaje i rozwija się w związku z zainteresowaniem ludzi nowymi celami wychowania, formacji młodych pokoleń we wspólnocie społecznej i jego grupach odniesienia, dzięki czemu zyskuje sobie rzesze zwolenników (Nawroczyński, 1987, s. 489-490). Czynnikiem łączącym jest przede wszystkim specyficzny sposób podejścia do postrzegania rzeczywistości edukacyjnej, wychowawczej oraz źródeł stanowienia celów.

Przenoszenie do pedagogiki współczesnej, wprost z polityki modelu antagonistycznego, podziału istniejących paradygmatów pedagogicznych, na ,swoje” i „obce”, na „przyjazne” i „wrogie”, będzie oznaczało powrót do zimnowojennej, totalitarnej gry na rzecz niszczenia, wyparcia, całkowitej likwidacji wszystkich tych doktryn i idei, które nie mieszczą się w kategorii odpowiadającej władzy, a więc w kategorii: „my”, ,nasi”, „,swoi”, czyli politycznie, aksjologicznie i ideologicznie ,poprawni”. To właśnie w tak antagonistycznie konstytuowanym dyskursie i praktyce edukacyjnej każdy ,inny”, „obcy”, „odmienny” jest wrogiem, zagrożeniem, niepożądanym przez władze rodzajem czy typem kierunku myśli, teorii lub doktryn, z którymi nawet nie ma co polemizować, tylko należy je zniszczyć, by to one nie doszły do władzy i nie zakwestionowały dominującej tożsamości. Nie warto godzić się z tak konstruowaną rzeczywistością, w której nie ma możliwości na przekroczenie podziału „my-oni”, gdyż poza logiką antagonistyczną istnieje jeszcze nieantagonistyczna, która nie prowadzi do praktyk dyskryminacyjnych wobec innych, nie przenika przez życie 
zbiorowe, starając się nim zawładnąć i narzucić mu jedynie słuszny, prawdziwy i obowiązujący kanon.

Chrześcijaństwo „(...) staje się coraz mniej religią europejską, a coraz bardziej religią o prawdziwie światowym zasięgu" (Nawroczyński, 1987, s.15). Zachodzące $\mathrm{w}$ świecie przenikanie różnych paradygmatów, założeń i teorii sprzyja wychwyceniu wspólnoty kierunków wspomnianych nauk i ich integralnego wpływu na życie człowieka, jego środowisk socjalizacyjnych i edukacyjnych. To dzięki chrześcijaństwu możliwe było stworzenie w państwach totalitarnych wspólnego frontu „(...) obrony przed bezbożnymi ideologiami marksistowską i faszystowską" (Nawroczyński, 1987, s. 158), a w ostatnich dekadach przed ideologią neoliberalną i anarchistyczno-lewicową. Należycie przygotowani do uczestniczenia w stałej odnowie Kościoła katolicy powinni sięgnąć do wiedzy na temat istniejących doktryn i historii, podstaw duchowego i liturgicznego życia, psychologii religii, ale i pedagogiki religii, pedagogiki chrześcijańskiej, by wspierać ruch ekumeniczny w jego zbliżaniu się do celu, jakim jest chrześcijańska jedność.

Jak trafnie wskazuje na granice ekumenicznych wysiłków w tym zakresie Andrzej Napiórkowski, wynikają one z pięciu podstawowych przyczyn: po pierwsze „(...) brak recepcji doktrynalnych ustaleń, których dokonali teologowie. Po drugie strach i lęk przed konsekwencjami takich zastosowań w życiu Kościołów i wspólnot, gdyż to mogłoby rewidować i zmieniać ich tożsamość. Po trzecie, panująca w wielu wspólnotach zwyczajna obojętność i lekceważenie; brak głębszego zaangażowania wiernych, a niekiedy i duchownych w parafii. Po czwarte, Ruch Ekumeniczny ma swoich wrogów. Wystarczy wskazać na prężne działanie tradycjonalistów i fundamentalistów. Po piąte, niektóre problemy doktrynalne są nazbyt złożone i trudne. Wydają się wręcz nierozwiązywalne na obecnym etapie rozumienia Objawienia judeochrześcijańskiego" (Nawroczyński, 1987, s. 179).

Polska pedagogika może być dumna z praktycznych doświadczeń ekumenicznego Ruchu „Światło-Życie” Franciszka Blachnickiego, jak i wzmocnienia paradygmatu personalistycznego w dziełach i życiu Karola Wojtyły, szczególnie w jego rozprawie „Osoba i czyn” (1985) czy już jako Jana Pawła II w dziele „Pamięć i tożsamość” (2005), jak i ks. prof. Józefa Tischnera z jego etyką solidarności i diagnozą syndromu homo sovieticus (2005). Ich osobiste dzieła i charyzmatyczne postawy solidarności międzyludzkiej oraz chrześcijańskiej stworzyły podwaliny pod odsłonę patologii, antropologicznego błędu i upadek totalitaryzmu w Polsce oraz w bloku państw Środkowo-Wschodniej Europy. To właśnie solidarne,,chrześcijaństwo wygenerowało zmiany i rozwój polityczny, 
społeczny, gospodarczy i osobowy. Oddziaływanie „Solidarności” jest nie do przecenienia, zarówno dla samych Polaków, jak i dla całego europejskiego wyzwolenia człowieka" (Tischner, 2005, s. 265).

Tak jak Kościoły chrześcijańskie muszą podjąć wysiłek na rzecz ekumenizmu, ,(...) większą pracę nad uzgadnianiem religijnej doktryny ze współczesną nauką, aby głosić Ewangelię bardziej społeczną, czyli odnoszącą się w sposób o wiele bardziej zdecydowany do prawa do życia (dziecka poczętego), ekonomicznej nierówności, rasizmu, prześladowań, deprecjacji kobiety, głodu, militaryzmu, kwestii pokoju" (Tischner 2005, s. 418-419), tak też pedagogika współczesna nie może być bierna wobec powyższych zjawisk. Wciąż jednak wydaje się niespełniony postulat pedagogiki humanistycznej i ekumenicznej zarazem, w świetle której konieczna jest pedagogika konsekwentnie wykorzystująca zdobycze dziedzictwa myśli pedagogicznej wraz z wszystkimi znanymi teoretyczne próbami uporania się z tą problematyką, wbrew wszystkim przeszkodom, by mogła ona służyć „(...) maksymalizowaniu rozwoju ludzi ponad wyznaczone granice i zastane konwencje, role i doktryny, (...) osiąganiu kompetencji współdziałania i komunikowana się ludzi w imię ich zbiorowej i jednostkowej, każdego z nich emancypacji" (Kwieciński, 1984, s. 4). Szczególnie znaczącą rolę ma do odegrania pedagogika chrześcijańska, na której spoczywa zadanie włączenia się w systematyczne usuwanie niechęci, uprzedzeń, fałszywych opinii czy stereotypów na temat (nie-)możliwego pojednania między chrześcijańskimi wspólnotami, środowiskami wyznawców różnych religii.

Szczególny wkład w jej rozwój wnosi Mirosław Patalon, który napisałw 2009 r. monografię pt. Pedagogika ekumenizmu. Stanowi ona niezwykle cenne pogłębienie dyskursu naukowego w tym zakresie, bowiem autor dokonuje w niej - w oparciu o bardzo interesujące i nieobecne w dotychczasowych analizach źródła - konstrukcji pedagogiki ekumenizmu w paradygmacie procesualnym. W tym sensie jest to przełom nie tylko horyzontalny w owej myśli, ale i wertykalny. pierwszy odnosi się do pogranicza, jak i samych nauk teologicznych, które w swojej części podejmują także problemy kształcenia i wychowania, drugi zaś rzutuje na dalszy kształt myśli pedagogicznej nurtu humanistycznego, która znajduje swoje odniesienie do szeroko rozumianego procesu wychowania jako procesu właśnie, a nie jak wciąż usiłuje się utrzymać w centrum dominującej powszechnie jeszcze narracji - jako działanie czy wywieranie na kogoś wpływu.

Niezwykle trafny jest wybór procesualności jako paradygmatu interkonfesyjnego i interreligijnej hermeneutyki w ujęciu Johna B. Cobba, Jra, ale także mającej w tej rozprawie miejsce rekonstrukcji myśli chrześcijańskiej, którą zaj- 
mują się uczeni skupieni w Katolickim Uniwersytecie Lubelskim, Papieskiej Akademii Teologicznej, Chrześcijańskiej Akademii Teologicznej w Warszawie oraz w Uniwersytecie Śląskim. Myśl ta ma, jak się okazuje, znaczenie nie tylko w obszarze nauk teologicznych, ale w samej pedagogice, którą nie tyle odświeża, ile wyraźnie wzbogaca o zupełnie nowe argumenty na rzecz takiego właśnie podejścia do edukacji. Mamy tu bowiem do czynienia z nawiązaniem do - słabo wciąż jeszcze zakorzenionej w polskiej teorii wychowania i kształcenia - francuskiej i rodzimej filozofii wychowania z jej naturalistyczną orientacją, w świetle której wychowanie jest procesem, dialogiem.

Jeszcze nie wszyscy są przekonani, że stan pęknięcia, radykalnego odcięcia się polskiej humanistyki od monistycznej, zdegenerowanej ideologicznie pedagogiki socjalistycznej musi stać się trwałym osiągnięciem czasów transformacji społeczno-politycznej, posttotalitarnej czy postkolonialnej. Niektórzy mają nadzieję, że mimo wszystko w naukach o wychowaniu nadal będzie obowiązywać paradygmat pozytywistyczny, instrumentalny w służbie etatystycznej indoktrynacji czy urabiania społeczno-politycznego młodych pokoleń z wykorzystaniem struktur i procesów obowiązkowej oświaty. Niewątpliwie, Patalon reprezentuje tę część nowego pokolenia badaczy, które wykorzystało szansę, by przekazać społeczności uczonych wiedzę zdobywaną w poszukiwaniach badawczych, w wyniku nawiązywanych od lat kontaktów międzynarodowych z naukowcami krajów wolnych od różnego rodzaju autorytaryzmów.

W czasach przełomu postmodernistycznego, głoszącego koniec wielkich narracji, pojawienie się rozprawy na temat pedagogiki ekumenizmu potwierdza, że warto jeszcze sięgać po metarefleksję nad rzeczywistością wychowawczą. Nie jest bez znaczenia to, co przekazuje współczesnym pedagogom autor niniejszej rozprawy, która tylko pozornie wydaje się odległą od codziennej praktyki powszechnego kształcenia i wychowania. Pojawiła się wraz z nią szansa na zainteresowanie środowiska pedagogicznego oraz nauczycieli myślą, która wpisuje się w głęboki namysł nad istotą tych procesów oraz nad ich przesłankami aksjologicznymi, antropologicznymi i ontologicznymi.

Kategoria procesu była przez dziesiątki lat redukowana tylko i wyłącznie do behawioralnej jego wersji, a więc do wskazywania na działanie ludzkie, w tym także pedagogiczne, jako dynamiczny proces, który jest związany z celowym działaniem ${ }^{1}$. Upowszechnienie po II wojnie światowej w naukach hu-

${ }^{1}$ Por. w teologii np. Makselon J. (red.) (1990) Psychologia dla teologów, Kraków: PAT czy w pedagogice np. Zaborowski Z. (1973), Wstęp do metodologii badań pedagogicznych, Wrocław: Ossolineum. 
manistycznych terminów zaczerpniętych z nauk biologicznych i technicznych objęło m.in. pojęcie procesu, w wyniku czego - jak pisał Z. Zaborowski (1973, s. 51) - ,(..) w każdej prawie publikacji pedagogicznej pisze się o procesie wychowawczym, dydaktycznym, procesie kształcenia zawodowego itp.”. Fenomen procesu łączono z pojęciem struktury, by - nadając mu wymiar instrumentalny - można było ukryć jego zgodność z ideologią marksizmu-leninizmu i wąsko rozumianym empiryzmem.

Tymczasem Patalon sięga w swojej rozprawie do filozofii procesu, która jako stanowiąca całkowite zaprzeczenie mechanicyzmu rzutuje na współczesną filozofię wychowania i treści kształcenia religijnego obok - jakże zbliżonej do niej - filozofii spotkania. O ile mamy już w polskiej humanistyce dość dobrze opisaną filozofię wychowania jako inkontrologię, o tyle filozofia procesu czekała na dalsze rekonstrukcje i interpretacje. Punktem wyjścia do swoich analiz Patalon czyni poglądy Johna B. Cobba i Alfreda N. Whiteheada, konfrontując je zarazem z poglądami polskich uczonych, jak chociażby C. Rogowskiego, B. Milerskiego, P. Gutowskiego, J. Jusiaka, B. Ogrodnika czy W. Hryniewicza. Ten nurt myślenia, wciąż jeszcze mało znany w naszym kraju, a obecny głównie na uniwersytetach brytyjskich i amerykańskich, rozwija się na naszym kontynencie dopiero po II Soborze Watykańskim, znajdując już swoich zwolenników oraz wpisując się w myśl humanistyczną dwóch nurtów: w przypadku Whiteheada - personalizmu idealistycznego i absolutno-idealistycznego, zaś w przypadku J. Cobba - nurtu personalizmu panpsychologiczno-idealistycznego (Letz 2006, s. 14).

To właśnie z orientacji absolutno-idealistycznej wyłoniły się najróżniejsze typy amerykańskich personalistów, w większości o orientacji chrześcijańskiej, których przedstawiciele nawiązywali do myśli, tworzącej dzisiaj już piątą generację personalizmu - osadzonego w filozofii procesu i filozofii enwiromentalnej. Ten ostatni nurt filozofii personalistycznej znajduje już swoją aplikację w teoriach wychowania ekologicznego czy kształcenia enwiromentalnego, natomiast filozofia procesu napotyka na bariery społecznej akceptacji i adaptacji. Być może jest tak dlatego, że jest to bardziej podejście niż gotowe stanowisko. Może ono jednak stanowić kluczowy punkt widzenia dla rozwijającej się dynamicznie w ostatnich latach pedagogiki twórczości czy postpedagogiki.

Jak stwierdza w jednej ze swoich rozpraw Janusz Jusiak (brmw): „,...) kategoria stawania się oraz logicznie i rzeczowo powiązane z nią kategorie czasu i przemijania (lub upływu), a także kreacji lub wytwarzania, posiadają, łącznie biorąc - czyli w możliwym, co najmniej do pomyślenia, ich zintegrowanym ujęciu — dające się wykazać, w analizie konkretnych zagadnień i problemów, 
pierwszeństwo czy nadrzędność wobec takich kategorii metafizycznego opisu i wyjaśniania, jak: trwałość, niezmienność, rzecz, substancja, fundament, absolutystycznie zinterpretowana (w zgodzie z kanonami klasycznego racjonalizmu lub empiryzmu) całość, tożsamość, pełnia czy zupełność".

Można też rozpoznać bliskość tej filozofii do analiz socjologicznych ponowoczesnych społeczeństw w ujęciu Zygmunta Baumana (2007) czy do filozofii ambiwalencji w ujęciu Lecha Witkowskiego (2001). Ten ostatni zwracał uwagę na to, że dwoistość jest kategorią niezbędną w pedagogice, uczulającą nas na przestrzeń problematyki, chroniącą teorię i praktykę pedagogiczną przed skrajnymi wyborami. Podobnie pisze o teologii procesu Patalon w swojej rozprawie jako o teizmie dwubiegunowym, zakładającym dwoistość zarówno Boga, jak i zmiennej rzeczywistości, w której ma miejsce paradoksalne współistnienie pozornych przeciwieństw: niezależności i zależności, transcendencji i immanencji itp. Ontologia ambiwalencji pozwala nam dostrzec to, iż fakt wychowania może być traktowany jako mikroproces, w którym w określonym momencie coś powstaje i przemija zarazem, gdzie granice aktualizacji tożsamości uczestniczących w nim jednostek są płynne. Podstawą tego procesu jest dialog (łączność), dzięki któremu zachodzi między wychowawcą a wychowankiem określona relacja jako wyznacznik ich doskonałości (Śliwerski, 2001, 1998).

Należy zgodzić się z Patalonem (2007, s. 13), że filozofia procesu i relacji nie jest najlepszą próbą refleksji teoretycznej nad rzeczywistością, ale „(..) oferuje nam jednak niewątpliwie jedną z możliwych prób zrozumienia dokonujących się w naszej cywilizacji zmian, związanych z tym, że człowiek w świecie substancjalnych i trwałych rzeczy utracił poczucie szczęścia”. Struktura recenzowanej tu rozprawy jest logiczna i wyczerpująca, gdyż mamy w niej przejście od analizy teologii procesu, poprzez zaangażowanie społeczne i edukację procesualną do dialogu międzyreligijnego, gdzie każda z kluczowych w poszczególnych rozdziałach kategorii pojęciowych postrzegana jest nie jako dana, ale jako zadana. Poglądy Whiteheada na temat prawdy znakomicie korespondują z epistemologią postmodernistyczną, gdzie - jak się stwierdza - nie istnieje, a przynajmniej nie jest możliwa do uchwycenia przez ludzki umysł jedyna prawda.

W pluralistycznym świecie, w wyniku trwającej wojny dyskursów, które wzajemnie weryfikują swoje systemy myślowe: ,jedne twierdzenia upadają, drugie zaczynają obowiązywać; poszukiwanie prawdy jest więc ciągłym procesem, a poznanie nigdy nie będzie całkowite i ostateczne (...)" (Patalon, 2007, s. 23). Nie ma niepodważalnych form w dziedzinie prawdy naukowej i religijnej, toteż - jak pisze Patalon (2007, s. 26) za Whiteheadem - „drążenie każdej 
zawiłości myśli aż do ostatecznego rozwiązania to kwestia godności intelektualnej. (...) Sprzeczność doktryn to nie katastrofa, to szansa" To właśnie ze względu na zmieniającą się kulturę, na każdym z chrześcijan spoczywa obowiązek nieustannego aktualizowania teologii czy różnych systemów filozoficznych, które „nie są ani prawdziwe, ani fałszywe; są za to w odpowiednim czasie bardziej lub mniej użyteczne" (s. 34).

Patalon jako badacz współczesnej myśli teologicznej i pedagogicznej stawia w swojej rozprawie pytania, które mają swoje filozoficzne uzasadnienie i praktyczne egzemplifikacje. Dla nauk o wychowaniu zawsze istotne było poszukiwanie odpowiedzi na pytania: Kim jest człowiek? Skąd pochodzi? Dokąd zmierza? Dlaczego podejmuje pewne działania? Jaką rolę odgrywają w jego życiu idee? Dla pedagogów ważniejsze jednak mogą się okazać tak zasadnicze $\mathrm{w}$ ich zawodzie pytania, jak wynikające $\mathrm{z}$ treści niniejszej publikacji, a mianowicie: Jakie może być dobrodziejstwo dialogu? Jaka wiedza jest najbardziej wartościowa w sytuacji, gdy cechuje ją względność, kontekstualność i tymczasowość? Jaką wiedzę należy przekazywać wychowankom? Jakimi kierować się kryteriami w poszukiwaniu prawdy, by jej nie zawłaszczać i nie absolutyzować? Jaki rodzaj wiedzy jest satysfakcjonujący w życiu osobistym jednostki, skoro teologia procesu odrzuca obowiązującą wszystkich i zawsze religijną metanarrację? Czy nowym paradygmatem duchowego przewodnika powinien stać się zaangażowany intelektualista, praktycznie zorientowany teolog? Jak sprzyjać współistnieniu różnych paradygmatów?

Suma przemyśleń filozoficznych, teoretycznych i ideologicznych dotyczących istoty wychowania i kształcenia umożliwia ogląd interesujących zagadnień w odpowiednim kontekście i wymiarze, pozwala zrozumieć istotę tych zjawisk, a co najważniejsze przygotowuje do twórczego zaangażowana się $\mathrm{w}$ proces edukacyjny. Znajdziemy w tej rozprawie wsparcie merytoryczne dla takich nurtów współczesnej pedagogiki, jak, oprócz - pedagogiki religii, pedagogika dialogu, pedagogika serca, pedagogika niedyrektywna, pedagogika między- czy wielokulturowa, pedagogikę inkluzyjną, pedagogikę twórczości czy pedagogikę postmodernistyczną. „Edukacja powinna raczej polegać na uwalnianiu naturalnej wiedzy i umiejętności tkwiących w uczniu, rolą zaś nauczyciela jest twórcze inicjowanie tych procesów" (Patalon, 2007, s. 87).

W takim też ujęciu, zarówno teologia procesu, jak i odpowiadające jej założeniom pedagogie pełnią podobną rolę do sztuki, o co przed kilkudziesięciu laty upominał się w swoich rozprawach chociażby Bogdan Nawroczyński. Niewątpliwie, wpisywanie się teologii procesu w szeroko rozumiany humanizm wzmacnia każdą z analogicznych do niej pedagogii, konstytuuje przejście od 
pedagogiki pewności, autorytarnej do pedagogiki nieautorytarnej, pedagogiki nadziei. Wyznaczając za J. B. Cobbem Kościołom zaangażowanie w transformację świata, w którym funkcjonują, w tym w eliminację ubóstwa, bezrobocia, patriarchalizmu, kryzysu rodziny, uzależnień, seksizmu itp. zbliża się teologia procesu do pedagogiki emancypacyjnej. Współczesny Kościół powinien być awangardą nowego porządku, sprzyjać procesom inkluzji, powszechności i otwartości wobec wiary, w warunkach poszanowania w idei protestanckiego pluralizmu oraz zasad wolności, praw człowieka i równości.

Mamy w tej rozprawie do czynienia $\mathrm{z}$ wielokrotną pochwałą pluralizmu i relatywizmu, oparcia edukacji na idei przenikania perspektyw i maksymalnie szerokim wachlarzu światopoglądowym. Jak pisze Patalon (2007, s. 90): „Prawda jest nieuchwytna, wielopostaciowa, ukryta, subiektywna... i pewnie jeszcze czymś innym. (...) Akceptacja różnorodności, tolerancja, wolność, równość i poszanowanie dla terytorium innego wyznaczają kanony poprawności”. Autor uzasadnia, jak ważne jest w ponowoczesnej teologii przyjęcie postawy otwartości na wielość poglądów, teorii i dyskursów, sprzyjanie pojawianiu się nowych prądów myśli i działania oraz wchodzenie z nimi w dialog, gdyż sprzyja to rozwojowi nauki i żywotności chrześcijaństwa zarazem. „Wiedza i nauka przestają być traktowane jako zamknięta odpowiedź na pytania człowieka, stają się raczej punktem wyjścia do dalszych poszukiwań" (Patalon, 2007, s. 91). Pochwała pluralizmu nie wiąże się z koniecznością odstąpienia od własnego podejścia czy paradygmatu, gdyż konkurujące ze sobą teorie czy koncepcje powinny się równoważyć, a nie zwalczać. „Pluralizm zatem to ciągły dialog ludzi przekonanych o wyjątkowości własnych wartości, jednocześnie jednak pokornych i gotowych do dalszej nauki" (s. 97).

Wreszcie mamy w polskiej pedagogice znakomite rozprawy ks. Bogusława Milerskiego, obecnego Rektora Chrześcijańskiej Akademii Teologicznej w Warszawie. Pierwszą, a niezwykle cenną dla pedagogiki jest wydana w 1998 r. książka Religia a szkola. Status edukacji religijnej w szkole w ujęciu ewangelickim (Milerski, 1998), która znakomicie wpisuje się swoją treścią w pedagogikę porównawczą i politykę oświatową. Podejmuje w niej problem religii w polskich szkołach, która przywróciła rodzicom prawo do pobierania przez ich dzieci nauki religii w szkołach państwowych (od $1991 \mathrm{r}$. traktowanych już jako szkoły publiczne), zamiast - jak miało to miejsce do $1991 \mathrm{r}$. w punktach katechetycznych. Autor tej książki stoi na stanowisku, że to właśnie pedagogika religii, jako nauka syntetyzująca określoną tradycję teologiczną z dorobkiem nauk humanistycznych i społecznych, powinna oświetlać status teoretyczny i praktyczny edukacji w obszarze religii, czyniąc ją nie tylko bardziej zrozu- 
miałą dla społeczeństwa, ale i pozyskując je do realizacji za jej pośrednictwem zadań edukacyjnych. „Jak się bowiem wydaje, pomiędzy Kościołem i szkołą, a także pomiędzy teologią i pedagogiką możliwy jest dialog, i to dialog prowadzony w imię obrony podmiotowości człowieka" (Milerski, 1998, s. 11).

Milerski rekonstruuje zarówno teologiczny, jak i pedagogiczny dorobek środowisk ewangelickich $\mathrm{w}$ zakresie odpowiedzialności Kościoła za wychowanie człowieka. Jest on wciąż marginalnie traktowany w literaturze przedmiotu, a przecież dysponuje swoistą tradycją, poszukiwaniami teologicznymi i krytyczną refleksją nad istotą wiary religijnej oraz jej zaistnieniem w obszarze szkoły. Autor wpisuje hermeneutykę pedagogiki religii w szeroko kulturowy i głęboko historyczny kontekst oświeceniowych, romantycznych i pozytywistycznych dzieł przedstawicieli polskich koncepcji pedagogicznych, jak chociażby S. Staszica, J. Śniadeckiego, B. Trentowskiego, K. Libelta, E. Estkowskiego czy J.W. Dawida. W jego ujęciu, to właśnie luterańskie rozumienie zadań edukacji religijnej jako procesu odnowy życia prowadzi do jej uznania za istotny komponent kształcenia szkolnego oraz włączenie jej do procesu kształtowania u uczniów określonych sposobów samorozumienia i egzystencji. Ukazuje także na tle regulacji prawnych oraz w kontekście historycznym i wyznaniowym zakres zróżnicowania modeli edukacji religijnej w państwach członkowskich Unii Europejskiej, które przyjmują formę konfesyjną, ponadkonfesyjną bądź mieszaną.

Edukacja religijna powinna być dialektyką dydaktycznego transferu wiary i praktycznej odnowy życia. Skierowana do konkretnych ludzi ma ona doprowadzić ich nie tylko do jej recepcji, przyjęcia swoistego sposobu jej rozumienia, ale i bycia w świecie, jego egzystencjalnej reinterpretacji. Wiedza religijna zatem, stając się programem odnowy życia poprzez konfrontację człowieka z świadectwami wiary włącza Kościół i szkołę (z jej lekcjami religii) do współodpowiedzialności za jakość życia młodego pokolenia. Edukację religijną w szkole postrzega Milerski jako wtórną wobec treści i form przekazu religijnego, mającego miejsce w rodzinie i społeczności wyznaniowej. Pisze o tym w rozdziale 4 omawianej książki, przywołując poglądy na temat wychowania religijnego jednego z najwybitniejszych teologów protestanckich i humanistów niemieckich Fryderyka D. E. Schleiermachera oraz idee Marcina Lutra, dotyczące współodpowiedzialności Kościoła za wychowanie religijne w szkole.

Uwrażliwia przy tym na konieczność eklezjalnego zakorzenienia katechezy szkolnej, która z racji swojego niepełnego wymiaru przekazu sakralnego nie może być traktowana jako substytut wychowania religijnego w rodzinie i Kościele. Nie da się w klasie szkolnej nauczać ‘czystej Ewangelii’ i „właści- 
wego rozumienia sakramentów", toteż musi być ona uzupełniona m.in. o specjalne formy wychowania ordynowanego przez parafię w ramach na przykład przygotowywania uczniów do potwierdzenia swojej wiary. Kategorią łączącą perspektywę naukową teologii i pedagogiki okazała się hermeneutyka, która pozwala na rozumiejące nauczanie religii jako edukacji za pośrednictwem form kulturowych.

W protestanckiej pedagogice religijnej uformowała się pod koniec lat 50 . naszego wieku szkoła hermeneutyczna jako jedno z wielu możliwych podejść rozumiejących, na której czele stał Martin Stallman. To dzięki niemu nastąpiło nawiązanie dialogu pomiędzy przedstawicielami Kościoła i pedagogiki religijnej, która na nowo sformułowała podstawowy cel edukacji szkolnej, jaką miało być uzdolnienie człowieka do chrześcijańskiego rozumienia własnej egzystencji i otaczającego świata w świetle analizy tekstu biblijnego oraz do kształtowania i przemiany własnych sposobów bytowania, nowego rozumienia samego siebie, ukształtowania własnej tożsamości, a także zmiany jakości życia. Edukacja religijna miała stać się także dynamiczną siłą krytyczną, transformującą i uwalniającą, prowadząc jednostki do zmiany ich wyobrażeń religijnych oraz do autotransformacji.

Edukacji religijnej przypisuje się zadanie uodparniania dzieci i młodzieży na wpływy różnego rodzaju ideologii oraz przygotowanie do krytycznego wglądu w rzeczywistość na rzecz tworzenia lepszych stosunków międzyludzkich. Ma ona im nie tylko przybliżać symbole i obrazy, uwrażliwiać na sacrum, ale i uwalniać od symboliki blokującej bądź ograniczającej doświadczanie wiary. Co ciekawe, w dobie kryzysu wychowania, który wynika nie tylko z utraty sensu egzystencji przez młode pokolenie, ale i z kryzysu samej szkoły, w edukacji religijnej dostrzega się możność jego przezwyciężenia, o ile stanie się ona obszarem głębokiej refleksji nad podstawami życia człowieka w jego doczesnej egzystencji i dialogiem społecznym.

Jak wynika z badań socjologicznych, słabnie rola tradycyjnych instytucji religijnych i kościelnych, dogmatów wiary i wartości religijnych w społeczeństwach modernistycznych i ponowoczesnych, zaś człowiek zaczyna traktować religię rynkowo, „smakując” jej podobnie, jak innych towarów, co prowadzi do estetyzacji i prywatyzacji religijności. Obok zjawiska religijności selektywnej i obywatelskiej, pojawiają się procesy jej deinstytucjonalizacji oraz nowe ruchy religijne i parareligijne, co rzutuje na postawy młodzieży wobec nauczania religii w szkołach.

Milerski przywołuje w kontekście współczesnego dyskursu teologicznego i pedagogicznego trzy modele edukacji religijnej w szkole publicznej, a mia- 
nowicie: konfesyjno-katechumenalnej, ponadkonfesyjnej oraz konfesyjno-dialogicznej. W pierwszym ujęciu, reprezentowanym przez znaczny odsetek teologów ewangelickich w Polsce, katecheta jest nosicielem urzędu kościelnego, zaś prowadzone przez niego lekcje wpisywane są w formę misji Kościoła w środowisku szkolnym. Model ten, bardzo zresztą krytykowany za pomijanie dokonań współczesnej pedagogiki i przemian świadomości w nowoczesnych społeczeństwach, czyni edukację religijną w szkole odseparowanym od całości kształcenia humanistycznego i mało skutecznym elementem programu nauczania. Drugi z tych modeli osadzony jest w tradycji biblijnej ('historie biblijne'), nie mając charakteru dogmatycznego, traktuje edukację religijną jako swoistego rodzaju nauczanie o religii lub propedeutykę nauki konfirmacyjnej. Pozostawia się $\mathrm{w}$ nim realizację celów kościelnych katechezie parafialnej, rezygnując ze zwiastowania i poświadczania na rzecz obiektywnego informowania. Trzeci model edukacji religijnej jest „drogą środka”, dowartościowując znaczenie identyfikacji wyznaniowej, ale i będąc zarazem otwartym na dialog pedagogiczny, ekumeniczny i światopoglądowy. Proponuje on stworzenie bloku zajęć w ramach oświaty publicznej, składającego się z profilowanej konfesyjnie religii i etyki, otwierającej młodzieży drogę do dialogu i współpracy ekumenicznej czy światopoglądowej.

Ewangelicka pedagogika religijna wychodzi z założenia, że lekcje religii w szkole publicznej należy uzupełniać nauką konfirmacyjną w społeczności parafialnej, ukierunkowaną na życie wspólnotowe i liturgiczne Kościoła. Oznacza to, iż prowadzona w szkole edukacja religijna powinna być traktowana nie tyle jako forma delegowania na tę instytucję obowiązku przekazywania treści konfesyjnych, ile przede wszystkim jako obszar publicznej konkretyzacji odpowiedzialności Kościoła za wychowanie młodego pokolenia. Jak trafnie ujmuje to w zakończeniu całej rozprawy Milerski (1998, s. 312) - podstawowym ,punktem odniesienia dla tak rozumianej edukacji jest uczeń i jego dobro, i to nie tylko dobro uczniów biorących udział w nauczaniu, lecz również tych, którzy w nim nie uczestniczą" . Nadal musi być jednak prowadzony w tym zakresie dialog pomiędzy Kościołem i szkołą, teologią i pedagogiką.

W innej swojej rozprawie Milerski (1998a) przywołuje poglądy pedagogicznych autorytetów myśli humanistycznej, które wywodzą się z protestantyzmu a dotyczą nie tylko wartości i znaczenia życia religijnego człowieka, ale przede wszystkim istoty samego procesu edukacyjnego i wychowawczego wraz z jego centralną instytucją, jaką jest szkoła.. Jakże aktualna jest myśl Lutra, iż z racji zmieniającego się świata musimy też zmienić koncepcję systemu szkolnego. Dzięki edukacji jest bowiem możliwa zmiana człowieka i otaczaja- 
cego go świata, jej brak natomiast oznacza sprzyjanie diablu (Milerski 1998a, s. 12). Czyż nie warto w dobie upominania się o powrót do szkolnej edukacji idei kształcenia holistycznego przypomnieć, iż podstawową przesłanką antropologii pedagogicznej jest egzystencjalny wymiar kształcenia człowieka jako całości duszy i ciała?

To właśnie reformacja dała podwaliny pod późniejszą szkołę herbartowską, zaś wychowanie potraktowała jako jedno z najważniejszych zadań w obszarze świeckiego bytowania człowieka, by „(...) uczyniło ono z dzikiego zwierzęcia człowieka zdolnego zachować swoje człowieczeństwo" (Milerski 1998a, s. 18). Wychowanie prawdziwie humanistyczne, także wychowanie religijne, powinno być związane z wezwaniem do przejęcia przez ucznia odpowiedzialności za własne samozrozumienie i sposób egzystowania w świecie, a to oznacza, że nie może być ono skoncentrowane ani na pamięciowym przekazie treści katechizmowych, ani „quasi-nabożeństwowym” zwiastowaniu, lecz przede wszystkim na rozumieniu egzystencjalnym,,,(..) Dlatego też wychowanie rozumiejące opiera się przede wszystkim na egzystencjalnej interpretacji tekstów, w wyniku której odkrywane zostają przed uczniem nowe sposoby samozrozumienia i egzystowania w świecie" (Milerski 1998a, s. 122-123). Współczesna szkoła powinna zatem przywrócić rangę hermeneutycznemu badaniu historyczno-kulturowego dorobku ludzkości i jego egzystencjalnej interpretacji, by uczniowie mogli odkrywać nowe możliwości samorozumienia i orientacji w świecie.

Rozwój nauk humanistycznych i społecznych w sposób naturalny generuje płynność myśli, przenikania różnych dyskursów, „,performatywności kultur” także w zakresie kształcenia i wychowania. Wymaga to jednak zupełnie innego języka, innej struktury narracyjnej, co wcale nie oznacza, że lepszej lub wykluczającej pozostałe, jakie dotychczas są obecne w humanistyce. Mam tu na uwadze potrzebę pisania i mówienia o pedagogice, ale i zarazem pedagogiką. Musimy liczyć się z tym, że „sięgają po władzę” zwolennicy ruchów, ideologii, wyznań, które dotychczas uważane przez świat cywilizacji miłości, imperium humanum za „patologiczne”, niebezpieczne, dehumanizujące czy wprost totalitarne, tworzą własną pedagogię jedności, bo wykluczeni pragną jakiejś przynależności, akceptacji lub możliwości odreagowania na innych za własne nieszczęścia. Wówczas, jak pisze Klaus Theweleit (2016, s. 75), „Ku tej pustce ciągną wszyscy ci, których ciała pragną sprawować władzę, posprzątać bałagan raz a dobrze, zrobić „porządek”. Lub ci, których interes poszukuje przestrzeni, w której ich kryminalne zapędy pozostaną bezkarne.” To, co ich łączy, to radość zabijania innych, upokarzania ich, dewastowania ludzkich dusz i ciał, ludobójcy, często „niezrzeszeni” mordercy, terroryści, którzy odwołują się do nowo- 
czesnej kultury przemocy, inscenizując swoje czyny przez ich upublicznianie w Internecie i nadając egzekucjom brutalny, a zarazem odświętny charakter. „Dokonywane zabójstwa mają pokazać ich władzę, przyciągnąć zwolenników, odstraszyć przeciwników i utrzymywać na stale wysokim poziomie czynnik zabawy" (Theweleit 2016, s. 53).

Brońmy cywilizacji miłości. Jeżeli - jak pisał Robert K. Merton (1982, s. 153): „nie wiemy, czy to co mówimy, jest prawdziwe” , to uznajmy i czyńmy zgodnie z tym, że jest to przynajmniej doniosłe. Współczesna myśl pedagogiczna jest niewątpliwie odzwierciedleniem swojej epoki, dominujących w niej systemów czy konstelacji wartości. Wychowanie i myśl pedagogiczna są też ściśle związane z poszczególnymi narodami i państwami. Można jednak mówić o współczesnych prądach pedagogicznych, których idee zrodzone w określonych warunkach odrywają się niejako od terytorium pochodzenia i twórcy, przekraczając najdalsze granice, docierając wszędzie, gdzie człowiek kulturalny interesuje się sprawami wychowania. Mają zatem obieg światowy. Fundamentalne dla naszej kultury prądy pedagogiczne trwają w historii dzięki ich nieustannej reinterpretacji. Jak mówił Paul Ricoeur: „Naszym punktem wyjścia nie jest nicość, zawsze jesteśmy, jak lubię mówić, zadłużeni. Ale to dziedzictwo jest nam powierzone po to, byśmy je rozwijali. To znaczy, że tradycja nie jest martwym depozytem, ale zasobem, który należy twórczo wykorzystywać. Powiedziałbym więcej - jednym z obowiązków wobec owego dziedzictwa jest też ożywianie martwych elementów przeszłości, martwych w tym sensie, że każda przeszłość zawiera pewne obietnice, które nie zostały ziszczone. Trzeba więc dostarczyć przeszłości jej własną przyszłość, która nie została spełniona"2 O ponadczasowej wartości ekumenizmu świadczy światowy ruch Focolare , który jest nośnikiem pedagogii jedności.

\section{Bibliografia:}

Bauman Z. (2007). Szanse etyki w zglobalizowanym społeczeństwie. Kraków: Wydawnictwo Znak.

Burszta W. J., Kuligowski W. (1999). Dlaczego kościotrup nie wstaje. Ponowoczesne pejzaże kultury. Wstępem opatrzył Zygmunt Bauman, Warszawa: Wydawnictwo Sic!

Hermann U. (1996). Pädagogisches Argumentieren und Erziehungswissenschaftliche Forschung.: zur Verhältnisbestimmung der beiden Wissens- und Diskursformen 'Pädago-

2 Prawda nigdy nie jest naga. Z prof. Paulem Ricoeurem, filozofem, rozmawia Jacek Poprzeczko, Polityka 1993 nr 28, s. 23. 
gik' und 'Erziehungswissenschaft'. W: Hoffmann D. (red.), Bilanz der Paradigmendiskussion in der Erziehungswissenschaft. Leistungen, Defizite, Grejzen, 2. Auflage, Weinheim: Deutscher Studien Verlag.

Jan Paweł II (2005). Pamięć i tożsamość. Rozmowy na przełomie tysiącleci. Kraków: Wydawnictwo ZNAK.

Jaworski P. (2000). Brońmy polskiej szkoły. Nasz Dziennik (wkładka edukacyjna poświęcona podstawom programowym reformy edukacji z dn. 9-10 września)

Jusiak J. (brmw). Współczesna filozofia procesu. http://bacon.umcs.lublin.pl/ jjusiak/wspolczesna-filozofia-procesu/\#1

Kojder A. (2016). Pobocza socjologii. Warszawa: Oficyna Naukowa.

Kunowski S. (2000). Problematyka wspótczesnych systemów wychowania, Kraków: Oficyna Wydawnicza „Impuls”.

Kwieciński Z. (1984). O edukację i pedagogikę radykalnie humanistyczną. Preprint referatu wygłoszonego w czasie Konferencji Naukowej Komitetu Prognozowania Perspektywicznego Rozwoju Kraju „POLSKA 2000”, Jabłonna, 29 listopada - 1 grudnia.

Kwieciński Z., Witkowski L. (red.) (1990). Ku pedagogii pogranicza. Toruń: Wydawnictwo UMK.

Letz J. (2006). Personalistické metafyziky, Typi Universitatis Tyrnaviensis, Trnava: VEDA Vydavatel'stvo Slovenskej Akadémie Vied.

Machnikowski R.M. (2002). Spór o relatywizm w XX-wiecznej socjologii wiedzy naukowej. Łódź: Wydawnictwo UŁ.

Makselon J. (red.) (1990). Psychologia dla teologów. Kraków: PAT, Kraków.

Marzec J. (2002). Dyskurs. Tekst. Narracja. Szkice o kulturze ponowoczesnej. Kraków: Oficyna Wydawnicza „Impuls”.

Merton R. K. (1982). Teoria socjologiczna i struktura spoleczna. Warszawa: Wydawnictwo Naukowe PWN.

Milerski B. (1998). Religia a szkoła. Status edukacji religijnej w szkole w ujęciu ewangelickim. Warszawa: Wydawnictwo Chrześcijańska Akademia Teologiczna.

Milerski B. (red.) (1998a). Elementy pedagogiki religijnej. Warszawa: Wydawnictwo Naukowe ChAT.

Nawroczyński B. (1987). Współczesne prądy pedagogiczne. W: Nawroczyński B., Dzieła wybrane, t. 1, wybór, przedmowa i wstęp A. Mońka-Stanikowa, Warszawa: WSiP.

Palouš R., Svobodová Z. (2011). Homo educandus. Filosofické základy teorie výchovy. Praha: Nakladatelství Karolinum. 
Panas W. (1991). W kręgu metody semiotycznej. Lublin: WN KUL.

Patalon M. (2007). Pedagogika ekumenizmu. Gdańsk: Wydawnictwo UG.

Prawda nigdy nie jest naga. Z prof. Paulem Ricoeurem, filozofem, rozmawia Jacek Poprzeczko, Polityka 1993 nr 28.

Szymański M. S. (1997). Podstawowe kierunki myślenia pedagogicznego w Niemczech. Kwartalnik Pedagogiczny, nr 3-4.

Śliwerski B. (1998). Program wychowawczy szkoły. Warszawa: WSiP.

Śliwerski B. (1998). Współczesne teorie i nurty wychowania. Kraków: Oficyna Wydawnicza „Impuls”.

Theweleit K. (2016). Śmiech morderców. Breivik i inni. Psychogram przyjemności zabijania. Zanim SS sięgnęlo po władzę, nawet Himmler był zwyktym ,, Templariuszem”. Breivik: niezrzeszony esesman. Przeł. Piotr Stronciwilk. Warszawa: PWN.

Tischner J. (2005). Etyka solidarności oraz Homo sovieticus. Wyd. 2 rozszerzone. Kraków: Znak.

Witkowski L. (2001). Dwoistość w pedagogice Bogdana Suchodolskiego (Z aneksem o Sergiuszu Hessenie). Kraków:Wydawnictwo Wit-Graf.

Wojtyła K. (1985). Osoba i czyn. Kraków: Polskie Towarzystwo Teologiczne.

Zaborowski Z. (1973). Wstęp do metodologii badań pedagogicznych. Wrocław: Ossolineum. 